УДК: 341.242.008.3 (061.1€С: $(477+478+479.22))$

\title{
ASSOCIATION AGREEMENTS BETWEEN THE EU AND UKRAINE, MOLDOVA AND GEORGIA: LEGAL AND CONSTITUTIONAL CHALLENGES OF IMPLEMENTATION
}

\author{
Roman Petrov* \\ National University of "Kyiv-Mohyla Academy», \\ Hryhoriya Skovorody Str. 2, 04655 Kyiv, Ukraine, \\ e-mail:petroveulaw@gmail.com
}

This contribution deals with the legal and constitutional aspects of the implementation of the association agreements between the EU and Ukraine, Moldova and Georgia in a comparative perspective. It argues that the legal frameworks of the association agreements, which have the objectives to establish a unique form of political association and economic integration, are characterised by three specific features: comprehensiveness, complexity and conditionality.

After a brief background of the EU relations with Ukraine, Moldova and Georgia, the following aspects are scrutinised: legal basis and objectives, institutional framework and mechanisms of enhanced conditionality and legislative approximation. In addition, constitutional challenges for the effective implementation of the association agreements between the EU and Ukraine, Moldova and Georogia are discussed.

Based upon a comparison with other EU external agreements, it is demonstrated that the association agreements are innovative legal instruments providing for a new type of integration without membership.

Key words: association agreements, the European Union, Ukraine, Moldova, Georgia, constitutions, implementation.

\section{Introduction}

The solemn signature of the AAs between the EU and Ukraine, Moldova and Georgia took place the EU Summit in Brussels on 27 June 2014 which followed by ratifications by national parliaments in Moldova, Georgia and Ukraine. ${ }^{1}$ This long

\footnotetext{
*Jean Monnet Chair and Head of Jean Monnet Centre of Excellence at National University of KyivMohyla Academy.

${ }^{1}$ Moldovan Parliament expediently ratified the Association Agreement on 2 July 2014. It shortly followed by the ratification by the Georgian Parliament on 18 July 2014. The final accord was played during the simultaneous ratification of the Association Agreement by Ukrainian Parliament and the European Parliament (ratified all three agreements) on 16 September 2014. Meanwhile all three association agreements are under lengthy process of ratification by parliaments of the EU Member States. Therefore the interim application of the association agreements is taking place in accordance with the EU Council decisions (Council Decision 2014/295/EU of 17 March 2014 and COM(2014)609). Application of Title IV (deep and comprehensive free trade area) of the EU-Ukraine Association Agreement has been postponed till 1 January 2016 due to political and security pressure of the Russian Federation.
}

(C) Petrov Roman, 2014 
awaited event culminated the end of very long negotiation and signature process that has been lasting since 2008. Ukraine's road towards the signature of the AA was the most dramatic. Due to mounting economic and political pressure from Russia the Government of Ukraine decided to suspend the process of preparation for signature of the EU-Ukraine AA on 21 November 2013. ${ }^{1}$ Following this news, hundreds of thousands of Ukrainians went to the streets. The «Maidan» revolution, which claimed more than 100 victims, resulted in the dismissal of President Victor Yanukovich on 22 February 2014 and election of pro-European new president Petro Poroshenko on 25 May 2014. As a consequence, the «most ambitious agreement the EU has ever offered to a partner country» $[1]^{2}$ is back on the agenda and was signed along with the Moldovan and Georgian AAs on 27 June 2014 [2]. ${ }^{3}$

Entering into force of the AAs will inevitably lead to the consideration of the legal and constitutional challenges of these agreements on the legal systems of Ukraine, Moldova and Georgia. Yet there is no straightforward clarification of these issues because the AAs are going to be very first framework international agreements in the modern history of Ukraine, Moldova and Georgia which imply their deep and far reaching integration into the legal order of supranational international organisation.

Taking the above as a starting point, the aim of this contribution is to analyse what constitutional challenges will arise before Ukraine, Moldova and Georgia in the course of implementation of the AAs into their legal systems. The paper focuses on two major challenges to this intricate process. The first challenge is how to ensure effective implementation and application of the AAs within the Ukrainian, Moldovan and Georgian legal orders. The second challenge is how to solve potential conflicts between the AAs and the Constitutions of Ukraine, Moldova and Georgia.

2. Objectives and specific features of the Association Agreements with Ukraine, Moldova and Georgia

The AAs between the EU and Ukraine, Moldova and Georgia are the most voluminous and ambitious among all EU association agreements with third countries [3]. ${ }^{4}$ These are comprehensive mixed agreements based on Article 217 TFEU (association agreements)

${ }^{1}$ The Ukrainian government's decision cannot be disconnected from the Russian proposal to establish a Eurasian Union building upon the already existing customs union between Russia, Belarus and Kazakhstan. On the background of this initiative and its implications for EU-Ukraine relations, see: G. Van der Loo and P. Van Elsuwege, «Competing Paths of Regional Economic Integration in the Post-Soviet Space: Legal and Political Dilemmas for Ukraine», 37 Review of Central and East European Law (2012), 421-447.

${ }^{2}$ H. Van Rompuy, Press remarks by the President of the European Council following the EU-Ukraine Summit, Brussels, 25 February 2013 (EUCO 48/13).

${ }^{3}$ European Council, «Statement at the signing ceremony of the Association Agreements with Georgia, Republic of Moldova and Ukraine», Brussels, 27 June 2014, EUCO 137/14. Available at: <http://www. consilium.europa.eu/uedocs/cms_data/docs/pressdata/en/ec/143415.pdf $>$, accessed 10 December 2014.

${ }^{4}$ For example, the EU-Ukraine AA comprises 7 titles, 28 chapters, 486 articles, 43 annexes on about 1000 pages. 
and Articles 31(1) and 37 TEU (EU action in area of Common Foreign and Security Policy [4]). ${ }^{1}$ There are many novelties introduced to these agreements. Most prominent of them are strong emphasis on comprehensive regulatory convergence between the parties and possibility for the application of the vast scope of the EU acquis within the Ukrainian, Moldovan and Georgian legal orders. Of particular significance of the AAs is the ambition to set up a Deep and Comprehensive Free Trade Areas (DCFTA), leading to gradual and partial integration of Ukraine, Moldova and Georgia into the EU Internal Market. Accordingly, the AAs belong to the selected group of «integration-oriented agreements», i. e. agreements including principles, concepts and provisions which are to be interpreted and applied as if the third country is part of the EU. It is argued that the AAs are unique in many respects and, therefore, provide a new model of integration without membership.

The AAs with Ukraine, Moldova and Georgia are innovative legal instruments which in opinion of Prof. Peter Van Elsuwege are characterised by three specific features: comprehensiveness, complexity and conditionality. ${ }^{2}$ The AAs are comprehensive framework agreements which embrace the whole spectrum of EU activities from setting up deep and comprehensive free trade areas (DCFTA) to cooperation and convergence in the field of foreign and security policy as well as cooperation in the area of freedom, security and justice (AFSJ). ${ }^{3}$

The complexity of the AAs reflects a high level of ambition of Ukraine, Moldova and Georgia to achieve economic integration in the EU Internal Market through the establishment of the DCFTAs and to share principles of the EU's common policies. This objective requires comprehensive legislative and regulatory approximation including advanced mechanisms to secure the uniform interpretation and effective implementation of relevant EU legislation into national legal orders of Ukraine, Moldova and Georgia. In order to achieve this objective the AAs are equipped by multiple specific provisions on legislative and regulatory approximation including detailed annexes specifying the procedure and pace of the approximation process for different policy areas in more than 40 annexes and based on specific commitments and mechanisms identified in both the annexes and specific titles to the agreement.

${ }^{1}$ EU-Ukraine Association Agreement (OJ 2014 L161). EU-Moldova Association Agreement (Proposal for a Council Decision on the conclusion of the Association Agreement between the European Union and its Member States, of the one part, and the Republic of Moldova, of the other part, of 10 March 2014, COM(2014)146 final). EU-Georgia Association Agreement (Proposal for a Council Decision on the conclusion of the Association Agreement between the European Union and its Member States, of the one part, and Georgia, of the other part, of 10 March 2014, COM(2014)156 final).

${ }^{2}$ These features of the AAs were described by Peter Van Elsuwege in Guillaume Van der Loo, Peter Van Elsuwege, Roman Petrov «The EU-Ukraine Association Agreement: Assessment of an Innovative Legal Instrument» EUI Working Papers (Law) 2014/09.

${ }^{3}$ See Title II and III of the AAs. 
Furthermore the AAs are founded on a strict conditionality approach which links the third country's performance and the deepening of its integration with the EU. ${ }^{1}$ In addition to the standard reference to democratic principles, human rights and fundamental freedoms as defined by international legal instruments (Helsinki Final Act, the Charter of Paris for a New Europe, the UN Universal Declaration on Human Rights and the European Convention on Human Rights and Fundamental Freedoms), ${ }^{2}$ the AAs contain common values that go beyond classical human rights and also include very strong security elements such as the «promotion of respect for the principles of sovereignty and territorial integrity, inviolability of borders and independence, as well as countering the proliferation of weapons of mass destruction, related materials and their means of delivery». ${ }^{3}$

Apart from the more general «common values» conditionality, the AAs contain a specific form of 'market access' conditionality, which is explicitly linked to the process of legislative approximation. Hence, it is one of the specific mechanisms introduced to tackle the challenges of integration without membership. Of particular significance is a far-reaching monitoring of Ukraine's, Moldova's and Georgia's efforts to approximate national legislation to EU law, including aspects of implementation and enforcement. ${ }^{4}$ To facilitate the assessment process, the governments of Ukraine, Moldova and Georgia are obliged to provide reports to the EU in line with approximation deadlines specified in the Agreements. In addition to the drafting of progress reports, which is a common practice within the EU's pre-accession strategy and the ENP, the monitoring procedure may include «on-the-spot missions, with the participation of EU institutions, bodies and agencies, non-governmental bodies, supervisory authorities, independent experts and others as needed». ${ }^{5}$

3. Effective implementation and application of the AAs within the Ukrainian, Moldovan and Georgian legal orders

Implementation and application of the AAs within the legal systems of Ukraine, Georgia and Moldova will be governed by their national constitutional laws. Provisions of the constitutions of Ukraine, Georgia and Moldova on application of international agreements follow the same approach and provide that in case of conflict of the AAs provisions with their national legislation (excluding national Constitutions), the former prevails. Once duly ratified by the Parliaments of Ukraine, Georgia and Moldova the

${ }^{1}$ For example, the preamble to the EU-Ukraine AA explicitly states that «political association and economic integration of Ukraine within the European Union will depend on progress in the implementation of the current agreement as well as Ukraine's track record in ensuring respect for common values, and progress in achieving convergence with the EU in political, economic and legal areas [emphasis added].

${ }^{2}$ Arts. 2 EU-Ukraine, EU-Moldova and EU-Georgia AAs.

${ }^{3}$ Art. 2 EU-Ukraine AA and Arts. 3 EU-Moldova and EU-Georgia AAs.

${ }^{4}$ Art. 475 (2) EU-Ukraine AA, Arts. 448-449 EU-Moldova AA, Arts. 414-415 EU Georgia AA.

${ }^{5}$ Art. 475 (3) EU-Ukraine AA, Art. 450 EU-Moldova AA, Art. 416 EU Georgia AA. 
AAs will became an inherent part of their national legal systems as any other duly ratified international agreement. ${ }^{1}$

Relevant provisions of the Constitutions of Ukraine, Georgia and Moldova imply that, on the one hand, properly ratified AAs will not only be equated to the same status as national laws but will also enjoy a priority over conflicting national legislation. ${ }^{2}$ On the other hand, the AAs can not overrule conflicting provisions of the national Constitutions and the legal systems of Ukraine, Georgia and Moldova do not envisage direct enforceability of international agreements in the national legal order.

The AAs are not just ordinary international agreements but complex framework legal structures that contain not only specific norms that govern the functioning of the association relations and DCFTA between the EU and Ukraine, Moldova and Georgia but also envisage a possibility of application of the vast scope of the «pre-signature» and «post-signature» EU acquis ${ }^{3}$ within the legal system of the eastern neighbouring countries. The scope of the EU acquis to be applied by Ukraine, Moldova and Georgia covers not only EU primary and secondary EU laws but also EU legal principles, common values, and even case law of the ECJ as well as specific methods of interpretation of the

\footnotetext{
${ }^{1}$ Article 9 of the Ukrainian Constitution of 1996 provides that: «International treaties in force, consented by the Verkhovna Rada of Ukraine [Ukrainian Parliament] as binding, shall be an integral part of the national legislation of Ukraine. Conclusion of international treaties, contravening the Constitution of Ukraine, shall be possible only after introducing relevant amendments to the Constitution of Ukraine». Full text in English is available at http://www.president.gov.ua/en/content/constitution.html, last assessed 10 July 2014. Article 8 of the Moldovan Constitution of 1994 provides that: «The Republic of Moldova pledges to respect the Charter of the United Nations and the treaties to which she is a party, to observe in her relations with other states the unanimously recognized principles and norms of international law. The coming into force of an international treaty containing provisions contrary to the Constitution shall be preceded by a revision of the latter». Full text in English is available at http://ijc.md/Publicatii/mlu/legislatie/ Constitution_of_RM.pdf, assessed 10 December 2014. According to Article 6(2) of the Constitution of Georgia, an international treaty or agreement of Georgia unless it contradicts the Constitution of Georgia, the Constitutional Agreement, shall take precedence over domestic normative acts. Full text in English is available at http://www.parliament.ge/files/68_1944_951190_CONSTIT_27_12.06.pdf, assessed 10 December 2014.

${ }^{2}$ Article 19(2) of Law of Ukraine «On International Treaties of Ukraine» provides that «If duly ratified international treaty of Ukraine contains other rules then relevant national legal act of Ukraine rules of the respective international treaty should be applied». Article 19 of the Moldovan Law No. 595-XIV 'On International Treaties' of 24 September1999 states: «international treaties shall be complied with in good faith, following the principle of pacta sunt servanda. The Republic of Moldova shall not refer to provisions of its domestic legislation to justify its failure to comply with a treaty it is a party to» (Monitorul Oficial, 2 March 2000, No. 24). Article 6 (1) of the Law of Georgia «On International Treaties» states that an international treaty of Georgia is an inseparable part of the Georgian legislation. «Parlamentis Utskebani», 44, 11/11/1997.

${ }^{3}$ For more on application of «pre-signature» and «post-signature» EU acquis in the EU external agreements see R. Petrov «Exporting the acquis communautaire through EU External Agreements» (NOMOS, Baden-Baden, 2011).
} 
relevant EU acquis within the their legal systems. Hitherto, the Ukrainian, Moldovan and Georgian legal systems have not faced the necessity to implement and to effectively apply a dynamic legal heritage of an international supranational organisation. ${ }^{1}$ Subsequently, adherence of Ukraine, Moldova and Georgia to the dynamic EU acquis via the AAs will encapsulate a plethora of challenges to their national legal orders.

One of the serious challenges to be faced by the eastern neighbouring countries is reluctance of the judiciary in the eastern neighbouring countries to apply and effectively implement international law sources in their own judgments. ${ }^{2}$ In practice, the Ukrainian, Moldovan and Georgian courts refer mainly to international agreements which are duly signed and ratified by their national parliaments and which are self-executing within the Ukrainian legal system. Even in these cases, the correct application of international agreements is not guaranteed. It happens because one of the most important impediments for the application of international law by the Ukrainian, Moldovan and Georgian judiciary is the correct understanding of these international conventions by national judges. Application of the AAs by the eastern neighbouring countries' judiciaries will increase through increasing familiarity with the AAs and the EU legal order as well due to claims on behalf of Ukrainian, Moldovan and Georgian nationals based on provisions of the AAs and the EU «acquis». ${ }^{3}$

In the writer's opinion, the objective of effective implementation and application of the AAs may be achieved by issuing a special implementation law that will clarify all potential conflicts of provisions of this agreement with Ukrainian, Moldovan and Georgian legislative acts. For example, Ukraine has already gained some experience in ensuring the implementation and application of the European Convention of Human Rights (ECHR) which Ukraine ratified in 1997. The ratification of the ECHR by Ukraine took place by means of two laws. The first law was law on ratification of the ECHR wherein Ukraine

${ }^{1}$ May be with exemption of application of the EU sectoral «energy» acquis under the framework of the Energy Community which Ukraine joined in 2010. See R. Petrov «Energy Community as a Promoter of the European Union's «energy acquis» to its Neighbourhood», 38(3) Legal Issues of Economic Integration (2012), 331-35.

${ }^{2}$ R. Petrov and P. Kalinichenko, «The Europeanization of Third Country Judiciaries through the Application of the EU Acquis: The Cases of Russia and Ukraine», 60 International \& Comparative Law Quarterly, (2011) 325-353. This happens mainly due to: 1) the belief that international case law is not relevant to civil law systems; 2) the translation of case law and jurisprudence; 3 ) lack of translation of case law into Ukrainian to help judges adapt their decisions to best European standards. Furthermore, the Verkhovna Rada of Ukraine is not always expedient in solving conflicts between ratified international agreements and national legislation.

${ }^{3}$ More on judicial activism and voluntary application of the EU acquis in the eastern neighbouring countries see P. Van Elsuwege and R. Petrov, «Legal Approximation of EU Law in the Eastern Neighbourhood of the EU: Towards a Common Regulatory Space?», (Routledge Press, 2014). 
recognised the jurisdiction of the European Court on Human Rights (ECtHR). ${ }^{1}$ The second law was a special law on application of case law of the ECtHR in Ukraine. It imposed on Ukraine a duty of mandatory and timely execution of all judgments of the ECtHR related to this country. ${ }^{2}$ In accordance with these laws judgments of the ECtHR are being formally accepted by the national judiciary as sources of law and Ukrainian judges frequently refer to the ECtHR judgments in their decisions. However the rate of effective application of the ECtHR case law in Ukraine is considered as unsatisfactory and lags far behind other European countries. ${ }^{3}$

The special law on implementation of the AAs may solve much more complicated issues than the Ukrainian law on ratification of the ECHR in 1997. For instance, this law will face the necessity of clarifying how binding decisions of the Association Councils should be applied in Ukraine, Moldova and Georgia. Direct applicability of the Association Councils' decisions will depend on their undisputed acceptance by national judiciaries. The special law on implementation of the AAs must clarify whether the ECJ case law constitutes a part of the EU sectoral acquis contained in the AAs' annexes. This issue is of prime importance for the Ukrainian, Moldovan and Georgian governmental agencies and the judiciaries which will deal with interpretation of various elements of the EU sectoral acquis within their national legal orders. Another challenge is clarification of how the EU directives listed in the annexes to the AAs should be implemented into the legal system of Ukraine, Moldova and Georgia. In other words may this process take into account choice of form and method of implementation of the EU directives listed in the annexes to the AAs? Last but not least what are legal means of transposing the EU dynamic acquis into the Ukrainian, Moldovan and Georgian legal systems? All these issues will be novel for the relatively immature legal system of Ukraine, Moldova and Georgia and, therefore, have to be answered in the special law on implementation of the AAs.

Ukraine, Moldova and Georgia may study and apply experience of other third countries which signed association agreements with the EU and issued national laws on implementation of these agreements. For instance, in 2001 the Croatian Parliament ratified the Stabilization and Association Agreement (SAA) and at the same time enacted the Act on Implementation of the SAA which required implementation of all secondary association acquis but did not envisage its direct effect within the Croatian legal order. ${ }^{4}$ The

${ }^{1}$ Law of Ukraine «On Ratification of the European Convention on Human Rights 1950, First Protocol and protocols№ 2, 4, 7 and 11» of 17 July 1997, № 475/97-BP.

${ }^{2}$ Law of Ukraine «On Execution of Judgments and Application of Case Law of the European Court of Human Rights» of 23 February 2006, № 3477-IV.

${ }^{3}$ See the 7th Annual Report of the Committee of Ministers 'Supervision of the Execution of Judgments and Decisions of the European Court of Human Rights' in 2013. Available at http://www.coe.int/t/dghl/ monitoring/execution/Source/Publications/CM_annreport2013_en.pdf, last visited 10 December 2014.

${ }^{4}$ S. Rodin, «Requirements of EU Membership and Legal Reform in Croatia» (2001) 38 Politička misao 87-105. 
Norwegian Parliament adopted a statutory law on implementation of the EEA Agreement in 1992. This law granted provisions of the EEA Agreement and its secondary law a supremacy over conflicting national legislation. The Norwegian law on implementation of the EEA Agreement clarified that relevant EU regulations are to be implemented without change but the implementation of EU directives must take into account choice of form and method of implementation. ${ }^{1}$ In order to ensure effective application of the relevant EU acquis within myriad of sectoral agreements with the EU Switzerland adopted several implementation laws too. For example, Federal Law on Swiss Internal Market in 1996 mirrors most of the relevant EU acquis and Swiss Law on Federal Parliament ensures «euro compatibility» of Swiss law drafts with the EU acquis. ${ }^{2}$

4. Concluding remarks

To conclude, we have set out a number of considerations which lead us to believe that the signature of the AAs with the EU will trigger significant internal reforms in the eastern neighbouring countries. First of all, the future AAs will serve as a template for further political and economic reforms in these countries. The obligation to share the EU's common democratic values will imply regular monitoring by the EU institutions. Thereby this should prevent the eastern neighbouring countries from undemocratic practices. The new joint institutions set up under the framework of the AAs will help to pursue the programme of approximating the laws with the help of its binding decisions. The process of effective implementation of the AAs will constitute the greatest challenge for Ukraine, Moldova and Georgia. These countries have to prove their adherence to the EU's common democratic and economic values, and ensure the proper functioning of their deep and comprehensive free trade areas. The latter objective may be achieved only under the condition of establishing truly competitive market economies and the adoption of international and EU legal standards. Ukraine, Moldova and Georgia will be bound by decisions of the dispute settlement body established by the AAs. Following the widely-used practice in the EU's external agreements the AAs contain so-called «evolutionary» and «conditionality» clauses. These are provisions in the EU's external agreements with specific objectives (for instance, granting a visa-free regime, access to all freedoms of the EU Internal Market), the attainment of which is conditional either on certain actions on behalf of a party to an agreement (such as the elimination of trade barriers and uncompetitive

${ }^{1}$ Statute of 27 November 1992, nr. 109. For more detail see K. Bruzelius, «The Impact of EU Values on Third Countries' National Legal Orders: EU Law as a Point of Reference in the Norwegian Legal System» in F. Maiani, R. Petrov, E. Mouliarova (eds.), European Integration without EU Membership: Models, Experiences, Perspectives, European University Institute Working Papers (Max Weber Programme), 2009/10, 81-89.

${ }^{2}$ F. Maiani, «Legal Europeanisation as Legal Transformation: Some Insights from Swiss «Outer Europe» in F. Maiani, R. Petrov, E. Mouliarova (eds.), European Integration without EU Membership: Models, Experiences, Perspectives, European University Institute Working Papers (Max Weber Programme), 2009/10, 111-123. 
practices) or the effective functioning of democratic and market-economy standards (such as free and fair elections and fighting corruption).

Стаття надійшла до редколегї̈ 16.12.2014. Прийнята до друку: 20 грудня 2014 р.

\title{
СОГЛАШЕНИЯ ОБ АССОЦИАЦИИ МЕЖДУ ЕС И УКРАИНОЙ, МОЛДОВОЙ И ГРУЗИЕЙ: ПРАВОВЫЕ И КОНСТИТУЦОННЫЕ ВЫЗОВЫ ИМПЛЕМЕНТАЦИИ
}

\author{
Роман Петров \\ Национальный университет «Киево-Могилянская академія», \\ ул. Г. Сковороды, 2,04655 г. Киев, Украина, \\ e-mail:petroveulaw@gmail.com
}

В работе исследуются юридические и конституционные аспекты соглашений об ассоциации между ЕС и Украиной, Молдовой и Грузией в сравнительной перспективе. Утверждается, что соглашения об ассоциации, которые имеют целью создать уникальную форму политической ассоциации и экономической интеграции между ЕС и Украиной, Молдовой и Грузией, характеризуются тремя особенностями: комплексностью, сложностью и условностью.

В работе освещаются такие вопросы правового характера: правовые основания и цели соглашений об ассоциации между ЕС и Украиной, Молдовой и Грузией; институты и механизмы реализации политики условности; правовое регулирование сближения законодательства. Кроме того, в работе обсуждаются проблемы имплементации соглашений об ассоциации между ЕС и Украиной, Молдовой и Грузией в правовые национальные системы.

На основании сравнения с соглашениями ЕС с другими странами, было продемонстрировано, что соглашения об ассоциации между EC и Украиной, Молдовой и Грузией являются инновационными правовыми актами, которые обеспечивают интеграцию Украины, Молдовы и Грузии в ЕС без формального членства.

Ключевые слова: соглашения об ассоциации, Европейский Союз, Украина, Молдова, Грузия, конституция, имплементация. 


\title{
УГОДИ ПРО АСОЦІАЦЮ МІЖ ЕС І УКРАЇНОЮ, МОЛДОВОЮ ТА ГРУЗІЕЮ: ПРАВОВІ I КОНСТИТУЦЙНІ ВИКЛИКИ ІМПЛЕМЕНТАЦІ
}

\author{
Роман Петров \\ Наиіональний університет «Києво-Могилянська Академія», \\ вул. Григорія Сковороди, 2, Київ, 04655, Україна, \\ e-mail: petroveulaw@gmail.com
}

Досліджено юридичні та конституційні аспекти угод про асоціацію між ЄС і Україною, Молдовою і Грузією в порівняльній перспективі. Наголошено, що угоди про асоціацію, які мають на меті створити унікальну форму політичної асоціації та економічної інтеграції між ЄC і Україною, Молдовою та Грузією, характеризуються трьома особливостями: комплексністю, складністю й умовністю.

Проаналізовано такі питання правового характеру: правові засади та цілі угод про асоціацію між ЄС і Україною, Молдовою та Грузією; інститути та механізми реалізації політики умовності; правове регулювання зближення законодавства. Крім того, вивчено проблеми імплементації угод про асоціацію між ЄС і Україною, Молдовою і Грузією в правові національні системи цих країн.

На підставі порівняння з угодами $Є \mathrm{C}$ з іншими країнами показано, що угоди про асоціацію між ЄС і Україною, Молдовою і Грузією є інноваційними правовими актами, які забезпечують інтеграцію України, Молдови та Грузії в ЄС без формального членства.

Ключові слова: угоди про асоціацію, Європейський Союз, Україна, Молдова, Грузія, конституція, імплементація. 